DOI 10.18551/rjoas.2019-11.28

\title{
THE PERFORMANCE OF BROILERS GIVEN EUGENOL OF CLOVE LEAF ESSENTIAL OIL AS A FEED ADDITIVE
}

Tahir M.*, Doctoral Degree Student

Chuzaemi S., Widodo E., Lecturers

Faculty of Animal Husbandry, University of Brawijaya, Indonesia

Hafsah, Lecturer

Faculty of Animal Husbandry and Fisheries, University of Tadulako, Palu, Indonesia

*E-mail: tahir.untad@gmail.com

\begin{abstract}
Clove (Syzygium aromaticum L.) leaf extraction can produce $2-4 \%$ essential oil, containing $70-90 \%$ eugenol. Clove essential oil has biological activities, such as antibacterial, antifungal, insecticidal and antioxidant properties, and is used traditionally as a savoring agent and antimicrobial material in food. It becomes the basis for this research on the use of eugenol of clove leaf essential oil as a feed additive for broilers. Experimental treatments consisted of E0 (without the use of eugenol), E1 ( $0.5 \%$ eugenol in feed), E2 ( $1 \%$ eugenol in feed), and E3 ( $1.5 \%$ eugenol in feed). The addition of 0.5 to $1.5 \%$ eugenol in feed significantly reduced feed intake compared to the control, in which the higher the use of eugenol in feed was, the lower the feed intake would be. The addition of $0.5-1 \%$ eugenol of clove leaf essential oil numerically increased body weight gain of broilers, but not significantly different between the three treatments, while the addition of $1.5 \%$ eugenol significantly decreased body weight gain compared to the other three treatments. The addition of $1 \%$ eugenol in feed significantly increased the final body weight compared to the control, but not significantly different from the addition of $0.5 \%$ eugenol, while the addition of $1.5 \%$ eugenol significantly decreased the final body weight compared to other treatments. The addition of $0.5-1.5 \%$ eugenol in feed significantly reduced feed conversion compared to control, but not significantly different between the three treatments. The addition of $1 \%$ eugenol of clove leaf essential oil in feed provided optimum body weight gain and final body weight for broilers at 6 weeks of age of $2035.00 \pm 66.52 \mathrm{~g} /$ chicken and $2185.00 \pm 66.52 \mathrm{~g} /$ chicken, respectively with feed conversion of $1.61 \pm 0.06$.
\end{abstract}

\section{KEY WORDS}

Poultry, essential oil, eugenol, feed additive, treatment.

Broiler productivity is largely determined by the seed, feed, and maintenance management factors. Broiler seeds are available in various strains, causing farmers to select the desired seeds only. However, seed selection should be supplemented by high-quality feed and good maintenance management. The cost of feed in the broiler farming business occupies the highest cost of all production costs of $60-70 \%$. Production costs can be reduced with the use of cheap and efficient poultry feed ingredients. Therefore, farmers are expected to be able to make the most of available feed ingredients without ignoring the quality aspect of feed ingredients. Selection of the right feed ingredients as a mixture or supplement in feed plays a very important role in determining broiler productivity.

As an effort to maintain the efficiency of broiler production and provide livestock products safe for consumption, the use of antibiotics or alternative medicines in the broiler industry needs to be endeavored. The development shows an effort to use bioactive compounds derived from plants as an alternative to dangerous antibiotics, including the use of essential oils from various types of plants. Some plant species are known to contain essential oils with antimicrobial and antioxidant properties, including eugenol in clove essential oil which can prevent the growth of pathogens (Jay, 2000). The ability of essential 
oils to inhibit the growth of pathogens when mixed into chicken feed is expected to inhibit pathogenic bacteria in the gastrointestinal tract. Thus, non-pathogenic bacteria can multiply and work more optimally in reorganizing and helping the absorption of nutrients needed by livestock.

Clove (Syzygium aromaticum L) leaf extraction or distillation will produce $2-4 \%$ essential oil, with $70-90 \%$ eugenol content. Clove essential oil has biological activities, such as antibacterial, antifungal, insecticidal and antioxidant properties, and is used traditionally as a savoring agent and antimicrobial material in food (Lee and Shibamoto, 2001; Huang et al, 2002; Velluti et al, 2003). The high levels of eugenol contained in clove essential oil are responsible for its antimicrobial activities, in which phenolic compounds can denature proteins and react with cell membrane phospholipids changing their permeability (Briozzo et al, 1989; Dens and Ritchie, 1987).

The use of eugenol of clove leaf essential oil in feed is expected to improve broiler performance to produce high meat products with better quality. It is possible because eugenol of clove leaf essential oil has antimicrobial and antioxidant properties as well as functions as a growth booster. Besides, the eugenol compound of clove leaf essential oil can improve digestive enzymes so as to increase the performance/growth of livestock, in which a blend of essential oil components stimulates the secretion of digestive enzymes in chicken (Williams and Losa, 2001).

The research on the performance of broilers given eugenol of clove leaf essential oil in feed aims to evaluate the dosages of eugenol of clove leaf essential oil as a feed additive providing the best performance. It includes feed intake, growth, and feed conversion. The research results are expected to provide solutions on the use of synthetic antibiotics whose function is replaced by eugenol of clove leaf essential oil to produce safer meat products.

\section{METHODS OF RESEARCH}

Cage research to determine the performance of broilers given eugenol of clove leaf essential oil as a feed additive was conducted at the Experimental Cage Installation in Tondo Village, Palu City, Central Sulawesi Province.

Research materials used in this experiment were eugenol of clove leaf essential oil and 200 broilers of unsexed CP 707 strain produced by PT Charoen Phokphan. Each of 20 experimental cages was equipped with drinking water and feed containers. The basal feed consisted of yellow corn, rice bran, soybean meal, fish meal, DL-methionine, and lysine. The composition and nutritional content of feed are presented in Tables 1 and 2.

Table 1 - The composition of feed ingredients for basal feed

\begin{tabular}{ccc}
\hline No & Feed ingredients & Composition (\%) \\
\hline 1 & Yellow Corn & 55,00 \\
2 & Rice bran & 14,45 \\
3 & Soybean Meal & 15,75 \\
4 & Fish Meal & 14,55 \\
5 & DL-Methionine & 0,10 \\
6 & Lysine & 0,15 \\
\hline
\end{tabular}

Table 2 - Nutritional content and metabolic energy of basal feed

\begin{tabular}{cc}
\hline Nutrition and Metabolic Energy * & Amount (\%) \\
\hline Metabolizable Energy (kcal/kg) & 3110.04 \\
Crude protein (\%) & 21.98 \\
Crude Fat (\%) & 6.24 \\
Crude Fiber (\%) & 3.91 \\
Calcium (\%) & 1.00 \\
Phospor (\%) & 0.89 \\
Methionine (\%) & 0.58 \\
Lysine (\%) & 1.48 \\
\hline
\end{tabular}

Note: *Arranged based on the calculation results. 
This research was started with raising 1 day-old broilers (DOC) according to the standard procedure for raising broilers. Feeding according to treatment began at 1 week of age for 5 weeks (chickens at 42 days of age). This research study evaluated 4 treatments with 5 replications, so there were 20 experimental units. There were 10 chickens at 1 week of age in each experimental unit. Thus, total chickens in this research were 200 chickens. The experimental treatments were as follows:

E0 $=$ Basal feed without the addition of eugenol of clove leaf essential oil;

$E 1=$ Basal feed $+0.5 \%$ eugenol of clove leaf essential oil in feed;

$E 2=$ Basal feed $+1 \%$ eugenol of clove leaf essential oil in feed;

$\mathrm{E} 3=$ Basal feed $+1.5 \%$ eugenol of clove leaf essential oil in feed.

Assessment of the success rate of a broiler farming business can be conducted by measuring its performance. In this research, the measured performance included feed intake, body weight gain, feed conversion, and final body weight.

Feed intake is the difference between the given feed with the remaining feed in a certain period, by taking into account the scattered feed. Feed intake was calculated cumulatively, i.e. feed intake from the beginning to the end of the study (Aji, et al., 2011). The feed intake calculation formula is:

Feed Intake $(\mathrm{g} /$ chicken) $=$ Initial feed $(\mathrm{g})$ - Remaining Feed $(\mathrm{g})$

The value of body weight gain is a reflection of the broiler growth. Body weight gain is the difference between the final body weight and the initial body weight (Aji, et al., 2011). To assess growth patterns, weighing was conducted every week to calculate the weekly body weight gain. The body weight gain calculation formula is:

$B W G(g /$ chicken $)=B W_{\text {Final }}(g)-B W_{\text {Initial }}(g)$

Feed conversion reflects the extent to which the amount of feed ingested by a broiler can be converted into body weight gain. Feed conversion value shows feed efficiency (Aji, et al., 2011). The feed conversion calculation formula is:

$$
\text { Feed Conversion }=\frac{\text { Feed Intake }(g)}{\text { Body Weight Gain }(g)}
$$

The final body weight is the weighing results of chickens' body weights at the end of the $6^{\text {th }}$ week. Analysis of variance for completely randomized design (CRD) using the MS Excel 2013 data analysis program was performed on data obtained from observations during the research. If there was a significant effect, the LSD test was then conducted (Steel and Torrie, 1995).

\section{RESULTS AND DISCUSSION}

Performance data of broiler production (feed intake, body weight gain, feed conversion, and final body weight) during the research are presented in Table 3.

Table 3 - Feed Intake, Body Weight Gain, Feed Conversion and Body Weight of Broilers at six weeks of age

\begin{tabular}{lllll}
\hline Parameter & Treatment & & \\
\cline { 2 - 4 } & E0 & E1 & E2 & E3 \\
\hline Feed Intake & $3619.00 \pm 47.88^{\mathrm{a}}$ & $3316.00 \pm 59.31^{\mathrm{b}}$ & $3269.00 \pm 55.16^{\mathrm{b}}$ & $2853.00 \pm 117.93^{\mathrm{c}}$ \\
(g/chicken) & & & & \\
BWG (g/chicken) & $1931.00 \pm 39.12^{\mathrm{a}}$ & $1961.00 \pm 65.71^{\mathrm{a}}$ & $2035.00 \pm 66.52^{\mathrm{a}}$ & $1659.00 \pm 57.60^{\mathrm{b}}$ \\
Feed Conversion & $1.87 \pm 0.06^{\mathrm{a}}$ & $1.67 \pm 0.07^{\mathrm{b}}$ & $1.61 \pm 0.06^{\mathrm{b}}$ & $1.72 \pm 0.07^{\mathrm{b}}$ \\
Final Body Weight & $2073.00 \pm 40.09^{\mathrm{b}}$ & $2108.00 \pm 65.92^{\mathrm{ab}}$ & $2185.00 \pm 66.52^{\mathrm{a}}$ & $1804.00 \pm 60.97^{\mathrm{c}}$ \\
(g/chicken) & & & & \\
\hline
\end{tabular}

Note: Superscripts with different letters on the same line showed a very significant difference $(P<0.01)$. 
Statistical test results showed that the addition of eugenol of clove leaf essential oil in feed had a very significant effect $(P<0.01)$ on feed intake, body weight gain, feed conversion, and final body weight. The addition of $0.5-1.5 \%$ eugenol of clove leaf essential oil in feed significantly reduced feed intake compared to the control (E0). The addition of $0.5-$ $1.5 \%$ eugenol of clove leaf essential oil in feed had no significant difference. Although numerically, decreased feed intake with the increasing use of eugenol of clove leaf essential oil in feed tended to occur. The addition of $1.5 \%$ eugenol of clove leaf essential oil in feed (E3) significantly reduced feed intake $(P<0.01)$ compared to E0, E1, and E2.

Decreased feed intake with the increasing use of eugenol of clove leaf essential oil in feed was caused by the lower feed palatability. One factor causing decreased palatability is the spicy eugenol compound. Therefore, the higher use of eugenol of clove leaf essential oil in feed resulted in lower feed palatability which had an effect on decreased feed intake. According to Borazjanizadeh et al. (2011), the addition of cloves and oregano as an additive in broiler feed can reduce feed intake.

Although the addition of eugenol of clove leaf essential oil had a very significant effect ( $P<0.01$ ) on body weight gain, $0.5-1.5 \%$ use tended to increase body weight gain numerically. An increase in body weight gain in the 0.5 and $1.5 \%$ use of eugenol of clove leaf essential oil was inversely proportional to feed intake. This condition showed that $0.5 \%$ and $1 \%$ eugenol of clove leaf essential oil can increase feed digestibility. Thus, nutritional requirements for growth were fulfilled although feed intake tended to decrease.

In the addition of $1.5 \%$ eugenol of clove leaf essential oil in feed, body weight gain significantly decreased $(P<0.01)$ compared to other treatments. This condition might be caused by 2 factors, i.e.: (1). Although feed digestibility increased, the amount consumed was insufficient for broiler nutritional requirements for maximum growth, (2). The addition of $1.5 \%$ eugenol reduced feed intake and digestibility causing broiler nutritional requirements for maximum growth were not fulfilled. Therefore, the addition of eugenol as a feed additive for broilers was a maximum of $1 \%$ of feed to obtain maximum growth.

Body weight gain reflects the extent to which the feed consumed can provide benefits to growth. To assess broiler growth patterns, weighing was conducted every week to calculate the weekly body weight gain. Growth patterns of broilers fed with the addition of eugenol of clove leaf essential oil as a feed additive can be seen in Figure 1.

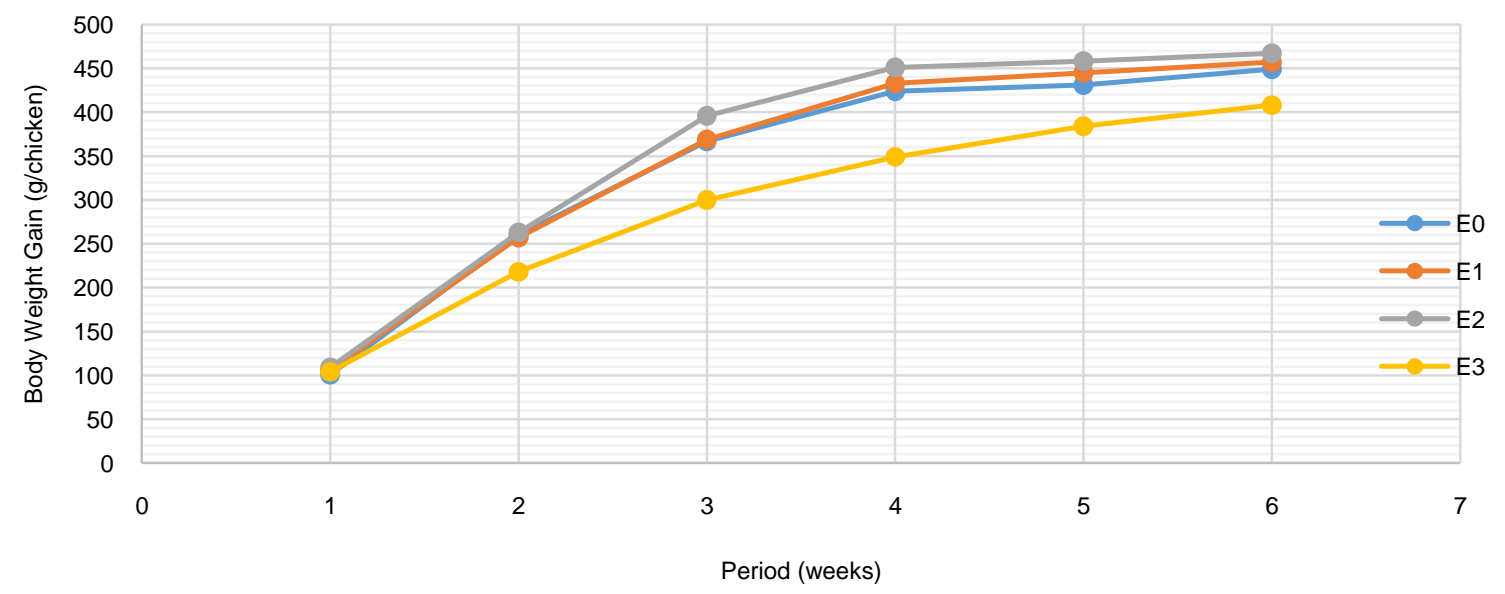

Figure 1 - Graph of Body Weight Gain

Based on Figure 1 Graph of weekly body weight gain, the addition of $1.5 \%$ clove leaf essential oil (E3) in feed gave lower weekly body weight gain compared to other treatments. As a result, body weight gain was low which affected final body weight. The graph also shows that the maximum growth rate occurred until the $4^{\text {th }}$ week in all treatments. Although growth continued until the $6^{\text {th }}$ week in all treatments, growth rates began to decline after the 
$4^{\text {th }}$ week. Figure 1 shows that after the $4^{\text {th }}$ week, the highest growth rate was the E3 treatment, while growth rates for the E0, E1 and E2 treatments tended to be constant.

Low growth rates with an increase in feed intake will have an effect on low feed efficiency. One parameter of feed efficiency is feed conversion. Broiler feed conversion value is the capacity of livestock to convert ingested feed into meat. Lower feed conversion value means higher feed efficiency. Table 3 shows that the addition of $0.5-1.5 \%$ eugenol of clove leaf essential oil in feed significantly decreased $(P<0.01)$ feed conversion value compared to control (E0). It shows that the addition of $0.5-1.5 \%$ eugenol of clove leaf essential oil in feed can increase feed efficiency in broilers until 6 weeks of age. These results are in line with Hussein et al's (2019) research results in quails, in which the addition of increased growth and body weight and decreased feed conversion in quails. It was further stated that dietary supplementation with antimicrobial $1.5 \mathrm{~mL}$ clove oil/kg feed could enhance growth performance, improve health status, and reduce intestinal pathogens in quails.

Although the addition of $0.5 \%$; $1 \%$ and $1.5 \%$ clove leaf essential oil in feed had no significant difference on feed conversion, numerically the addition of $0.5 \%$ and $1 \%$ decreased feed conversion value, while the addition of $1.5 \%$ increased feed conversion value albeit the value was lower than E0 (without the addition of eugenol of clove leaf essential oil in feed). Decreased feed conversion value (increased feed efficiency) with the addition of eugenol of clove leaf essential oil was caused by increased nutritional feed digestibility consumed.

Feed efficiency can be improved through the provision of an additive material or feed. Feed additives are commonly used in modern poultry farming business with the aims to spur growth or increase efficiency by reducing pathogenic microorganism population or increasing non-pathogenic microorganism population in the gastrointestinal tract as well as increasing livestock productivity.

Feed intake which impacts body weight gain with different efficiency will determine the final body weight. The addition of $1 \%$ eugenol of clove leaf essential oil in feed (E2) significantly increased the final body weight $(P<0.01)$ compared to E0. The addition of $0.5 \%$ eugenol of clove leaf essential oil in feed (E1) gave no significant difference $(P>0.01)$ on $E 0$ and E2. The E3 treatment (the addition of $1.5 \%$ eugenol of clove leaf essential oil in feed) gave significantly lower final body weight $(P<0.01)$ than the other three treatments $(E 0, E 1$, and E2). Low final body weight in the treatment E3 was the impact of low feed intake. Additionally, body weight gain was also low albeit feed efficiency was better than the E0 treatment.

\section{CONCLUSION}

Based on the research results on evaluation of the use of eugenol of clove leaf essential oil (Syzygium aromaticum, fam myrtaceae) as a feed additive for broilers, it can be concluded that the addition of $1 \%$ eaugenol of clove leaf essential oil in feed provided optimum body weight gain and final body weight for broilers at 6 weeks of age of $2035.00 \pm$ $66.52 \mathrm{~g} /$ chicken and $2185.00 \pm 66.52 \mathrm{~g} /$ chicken, respectively with feed conversion of $1.61 \pm$ 0.06 .

\section{REFERENCES}

1. Aji, S.B., K. Ignatius, A.Y. Ado, J.B. Nuhu, A. Abdulkarim, U. Uliyu, M.B. Gambo, M.A. Ibrahim, H. Abubakar, M.M. Bukar, H.A.M. Imam and P.T, Numan. 2011. Effect of feeding onion (Allium cepa) and garlic (Allium sativum) on some performance Characteristic of broiler chiken. Research Journal of Poultry Sciences. 4(2):22 - 27.

2. Borazjanizadeh, M., M. Eslami, M. Bojarpour, M. Chaji and J. Fayazi. 2011. The effect of clove and oregano on economic value of broiler chicken diet under hot weather of Khuzestan. J Anoe Vet Adv. 10:169-173.

3. Brizzo, J., L. Nunez, J.Chirife, L. Herszage and M. D’Aquino. 1989. Antimicrobial activity of clove oil dispersed in a concentrated sugar solution. Journal of Applied Bacteriology. 66 (1): $67-75$. 
4. Deans, S.G. and G. Ritchie, 1987. Antibacterial properties of plant essential oils. Int. J. Food Microbiol., 5: 165-180.

5. Jay, J.M. 2000. Modern Food Microbiology. Sixth Edition. Aspen Publisher, Inc.

6. Lee, K.G. and T. Shibamoto, 2001. Antioxidant property of aroma extract isolated from clove buds [Syzygium aromaticum (L.) Merr. Et Perry]. Food Chem., 74 (4): 443-448.

7. Huang Y, S.H. Ho, H.C. Lee and Y.L. Yap, 2002. Insecticidal properties ofeugenol, isoeugenol and methyleugenol and their effects on nutrition of Sitophilus zeamais Motsch. (Coleoptera: Curculionidae) and Tribolium castaneum (Herbst) (Coleoptera: Tenebrionidae). J. Stored Prod. Res., 38 (5): 403-412.

8. Hussein, M.M.A., M.E.A. El-Hack, S.A. Mahgoub, I.M. Saadeldin and A.A. Swelum. 2019. Effects of clove (Syzygium aromaticum) oil on quail growth, carcass traits, blood components, meat quality, and intestinal microbiota. Poultry Science. 98 (1): 319 - 329

9. Steel, R.G.D and J.H. Torrie. 1995. Prinsip dan Prosedur Statistik, Suatu Pendekatan Biometri. Cetakan keempat. P.T.Gramedia, Jakarta.

10. Velluti A, V. Sanchis, A.J. Ramos and S. Marı'n, 2003. Inhibitory effect of cinnamon, clove, lemongrass, oregano and palmarose essential oils on growth and fumonisin B1 production by Fusarium proliferatum in maize grain. Int. J. Food Microbiol, 89: 145-154.

11. Williams, P. and R. Losa, 2001 The use of essential oils and their compounds in poultry nutrition. World Poultry, 17(4): 14-15. 